\title{
BURNOUT SYNDROME IN RELATION TO THE SENSITIVITY OF NURSES, TEACHERS AND SOCIAL WORKERS \\ Júlia Fričová ${ }^{1}$, Katarína Kohútová ${ }^{2}$, Lenka Štefáková $^{3}$
}

\begin{abstract}
:
Background and objectives: Burnout syndrome is considered as a serious public health problem that affects workers especially in the helping professions. For the effective prevention of this negative phenomenon, it is important to identify the preventive factors. One such factor to combat job burnout is the meaning of life. The primary goal of the paper is to examine the relationship between burnout syndrome and different dimensions of meaning of life among the selected helping professions (teaching, social work and nursing) in Slovakia.

Methods: The research sample consisted of 212 assistants who participated in the survey and answered to the research tools aimed at identifying the meaning of life and burnout syndrome. Data were analyzed by inductive statistics including (ANOVA), correlation and regression analysis.

Results: Statistically significant differences were found in the level of burnout syndrome and meaning of life in the professions under study. Furthermore, it was found that workers with higher level of affective component in their meaning of life experienced a lower degree of emotional exhaustion $(\beta=-.37, \mathrm{p}<.001)$ and higher personal performance $(\beta=.35, \mathrm{p}$ $<.001)$. Workers who have a higher meaning in life in the affective and motivational component suffered from a lower degree of depersonalization $(\beta=-.49, \mathrm{p}<.001 ;(\beta=.13, \mathrm{p}<.05)$.

Conclusions: A higher degree of meaning in life result in lower rate of burnout syndrome, and this finding should be integrated into the intervention strategies aimed at the prevention and treatment of burnout syndrome. Regular reflections on the meaningfulness of work and life can be useful for the workers, especially during demanding and stressful periods. An existential approach seems to be very appropriate in this context.
\end{abstract}

UDC Classification: 305-055.1, 305-055.2, DOI: https://doi.org/10.12955/pss.v1.45

Keywords: Burnout, Life meaning, Nurses, Social workers, Teachers.

\section{Introduction}

Work has its specific role in an individual's life, it is not only a source of material security, but also of self-realization, it provides an individual with a certain order of life, regime, social background and, last but not least, emotional and social appreciation. It can be said that work determines a person's mental state and conversely, the mental state is reflected in the work performance. There are occupations that have greater impact on an employee's mental state, and individuals in these professions may be at greater risk of burnout and stress related problems than others. These are the socalled helping professions, which are characterized by constant contact with people and their demanding, often traumatic experiences and problems, the ambiguity of the professional role, excessive number of clients, lack of competencies, the need to withstand chronic stress, the absence of appreciation and quality of specific jobs conditions.

\section{Burnout syndrome in the professions of social workers, nurses and teachers}

Burnout syndrome is a negative phenomenon that is associated with the work environment, especially in helping professions. It affects the physical, mental, emotional and social aspects of the worker and arises as a result of an imbalance between "expenses" and "income", the worker has a subjective feeling that he invests a lot in work and the benefits are small in comparison. These professions are characterized by contact with other people whom the worker is to help. In most cases, burnout affects people who were originally very engaged, motivated, enthusiastic, passionate about work. After some time, especially if their lives are restricted to the work area, they run out of energy, the worker "gives" more than he "receives", his full work does not have such an effect that would correspond to this work and under the influence of chronic, long-term stress, he burns out. A worker whose primary job was to help and serve reaches to the stage when he needs help for himself.

Maslach (1982) provides an important description of burnout: "Burnout is a syndrome of emotional exhaustion, depersonalization and reduced personal accomplishment that can occur among individuals

\footnotetext{
${ }^{1}$ Catholic university in Ružomberok, Faculty of Eucation, Department of Social

Work,julia.fricova801@edu.ku.sk

${ }^{2}$ Catholic university in Ružomberok, Faculty of Education, Department of Social Work, katarina.kohutova@ku.sk

${ }^{3}$ Catholic university in Ružomberok, Faculty of Education, Department of Social Work, lenka.stefakova@ku.sk
} 
who do 'people work' of some kind". According to Pines \& Aronson (1983), burnout syndrome is a state of physical, emotional and mental exhaustion that occurs as a result of long-term persistence in situations that are extremely emotionally demanding. This emotional challenge most often occurs when high expectations are combined with chronic situational stress. Burnout is the end result of a process in which highly motivated and committed individuals lose their spirit (Pines, 2002).

In this study, burnout has been addressed in three helping professions - nursing, teaching and social work. The work of social workers is focused on providing care to clients from more vulnerable groups of the population (e.g. the poor, the elderly, people with disabilities, minorities, etc.). They are often in contact with clients who have experienced various traumatic experiences, as a result of which they are more prone to burnout and secondary traumatic stress. They are often involved in decisions with farreaching consequences, like entrusting a minor child to institutional care, etc. As Lloyd et al. (2002) pointed out the stressful nature of social work professionals, low self-esteem, lack of professional challenges, difficulties in providing client services as the risk factors related to burnout. Kohútová (2017) found that in Slovakia, $18 \%$ of social workers suffer from a high degree of burnout, $12.3 \%$ from low personal performance and $23 \%$ from depersonalization.

Another group vulnerable to burnout are nurses, who are expected to perform professional activities at a high level, work with modern technology, bear the physical burden of their work, influence and lead the survival and actions of patients, perform various administrative work and last but not least to cope with the problems at work and family that life brings. The nurse and the patient meet in a non-standard social situation and thus in specific social roles, which are not always fully mastered. The nurse is expected to instill confidence in the patient's expertise, show a high dose of tact and patience, and is often introduced to the patient's worries and problems, their moods, depression, or personality traits. Her role requires understanding, comprehension and kindness (Zacharová et al., 2007). The burnout syndrome in nurses is associated with a high workload, weak social support, the perception of an imbalance between investment and patient outcomes and a reduced sense of personal accomplishment (Pines, 2002). It is therefore a very demanding profession, which requires a high level of involvement in qualification training and in the practice of the profession itself, and health professionals belong to a group that is at high risk of burnout. This is also proved by several research studies like Pilárik \& Tobákošová (2013) found that in Slovakia, 34\% of nurses suffered from a high degree of emotional exhaustion, up to $50 \%$ of them with a low personal performance and $31 \%$ of nurses with a high degree of depersonalization. The emotional exhaustion of Spanish nurses ( $N$ 117) averaged 24.4, depersonalization 7.6 and personal accomplishment 34.5 (Soto-Rodríguez \& Peréz-Fernandez, 2015). Nantsupawat et al. (2016) surveyed the level of burnout syndrome in Thai hospitals, where $32 \%$ of nurses (N 2084) suffered from high levels of emotional exhaustion, $18 \%$ from depersonalization, and $35 \%$ from low levels of personal satisfaction.

The burnout syndrome in the teaching profession is related to the typical stressors of this profession. High administrative burden, problematic behavior of students, difficulties with maintaining discipline in the classroom, low financial evaluation, difficulties with students' parents, time constraints, inadequate working conditions, etc. are considered as stressors by the teachers (Bočáková \& Rolníková, 2005). Baranovská (2013) found that a third of Slovak teachers suffered from a high level of emotional exhaustion, almost all achieved high depersonalization scores and $65 \%$ suffered from personal dissatisfaction.

\section{Life meaningfulness in relation to the burnout syndrome}

One of the important factors that can be significant in relation to the burnout syndrome is the meaning of life. The main reason is that the meaning of life helps individuals to interpret and organize experiences (even challenging and stressful) within a certain meaningful framework and to identify important aspects of life. In general, the meaning of life can be defined as the reason for life, basic life goals and direction, or basic values for which a person lives (Halama et al., 2014). Reker \& Wong (1988) defined the meaning of life as an awareness of order, coherence and the purpose of one's own existence, effort and achievement of value goals, and an associated sense of fulfillment. The presence of the meaning in life allows individuals to live their lives with understanding and significance, instill in them a sense of purpose or mission in their daily lives (Krok, 2016). According to Reker and Woo (2011), ways of experiencing the meaning of life can be described using three components. The first is the cognitive component, which provides a consistent understanding of life and gives man and his life 
wholeness and meaning, it also provides an existential understanding of the meaning of various life events and puts them in an organized and coherent framework. The affective component refers to the experience of contentment, happiness and fulfillment that results from a meaningful life, and the motivational component refers to the effort and pursuit of goals. It contains a value system of life goals, which the individual chooses on the basis of his values.

The theoretical framework for understanding the relationship between the meaning of life and the burnout syndrome is an existential theory, which postulates that vital fulfillment is a prerequisite for the healthy functioning of an individual. The primary cause of burnout from an existential point of view lies in the need for individuals to find existential meaning in their lives and the feeling that the work they do does not provide it to them.

Frankl (1983) defined the existential vacuum as a loss of interest (leading to boredom) and a lack of initiative (leading to apathy). As a result, the loss of interest and initiative leads to a deep sense of nonsense. Based on his experience, Frankl has found that a person suffers the worst condition when he has nothing to live for or work for, has no goal or purpose in life. The predominant symptoms of burnout are similar to the two main symptoms of Frankl's existential vacuum: feelings of emptiness and nonsense (burnout syndrome also includes physical symptoms such as exhaustion). According to Frankl (1983), each individual has a will to make sense, which is his primary motivating force, and this force directs him to transcend himself and focus on the goal. Yalom (1980) saw a therapeutic response to the absence or loss of sense of engagement. He postulated that meaning, as well as pleasure, must be sought indirectly. A sense of purpose is a by-product of commitment. Full commitment to one of the many activities of life increase the possibility of an individual structuring the events of his life in a certain rational way.

The search for meaning and significance in employment provides individuals with motivation and stimuli for meaningful involvement and implementation of tasks (Krok, 2016). According to the existential approach, people need to believe that their lives are meaningful and that the things they do have meaning, benefits and even are "heroic." Realizing things that make sense helps to deal with existential anxiety stemming from the fear of one's own mortality. One of the ways to become a "hero" is to choose a job and career. People enter employment with great hopes, ideals and motivation and perceive their work as a mission. If they gradually feel that they have failed, their work is negligible, and that they will not change the world, they begin to feel helpless and hopeless and eventually burn out (Pines, 2002).

When people feel that their work is important and significant, they are more resistant to burnout, despite of high levels of stressors (Pines \& Keinan, 2005). Hooker et al. (2020) conducted research to determine the relationship between meaningfulness, burnout, fatigue, and quality of life in lead physicians. They found that doctors who had a higher level of life's meaning experienced lower burnout, fatigue, and higher quality of life. Singer et al. (2019) found that higher meaningfulness in life is negatively related to the burnout syndrome in social workers. Similarly, Allan et al. (2017) found that higher meaningful work is negatively related to burnout syndrome among counselors. Barnett et al. (2018) found that the meaning of life was associated with a lower rate of burnout syndrome in hospice nurses. Gama et al. (2014) found a similar relationship in nurses caring for the terminally ill and Slezáčková \& Ř́hová (2014) reported it among nurses in psychiatric wards. Nurses who had a higher meaning in life were personally more efficient, felt full and useful for patients and families, were less emotionally exhausted and depersonalized. Itzick et al. (2016) conducted a study on social workers, reported similar results with meaning in life negatively related to burnout. Kohútová (2017) investigated the connection between the meaning of life, personal faith, spirituality and the burnout syndrome in social workers and identified significant relationships. Similar results were obtained by Loonstra et al. (2009) in a research sample of teachers. Meriläinen (2014) identified a strong negative relationship between the meaning of life and the school burnout syndrome in a research sample of 3,035 Finnish university students. The results of the cited studies suggest that the meaning of life is related to work experience and subsequent burnout.

Meaningfulness in life can act as a preventive factor against burnout, because if an individual lives his or her meaningfully, it has a positive effect on his or her daily functioning, which can weaken the effects of emotional exhaustion, depersonalization and reduced competence. The aim of this study is to identify the relationship between the meaning of life and the burnout syndrome in selected helping 
professions (teaching, nursing and social work). To achieve the goal, following research question and hypothesis are established:

RQ1: Is there a significant difference in the level of burnout between teachers, nurses and social workers?

RQ2: Is there a significant difference in the level of meaning in life between teachers, nurses and social workers?

RQ3: Are the components of the meaning of life and selected demographic characteristics (age and profession) a determinant of the burnout syndrome?

$\mathrm{H}$ : There is a statistically significant relationship between the domains of burnout syndrome and the domains of meaning in life.

\section{Methods}

Participants and procedure

The research sample consisted of 212 respondents, who participated in the study voluntarily. 190 respondents were women and 22 were men at an average age of $38.61(\mathrm{SD}=9.751)$. The research sample consisted of respondents in helping professions, of which 88 (41.5\%) respondents were teachers, $82(38.7 \%)$ were nurses and $41(19.3 \%)$ were social workers from the district of Námestovo and Dolný Kubín (the participants were randomly recruited from the institutions in these districts). The data were obtained directly at the workplace. All participants completed self-administered questionnaires over a period of one week, which afterwards were collected by the researchers at work. The study was anonymous. Regarding education, $57.5 \%$ respondents have completed second level university education and, respondents with the same percentage of $18.4 \%$ have completed their first level university education and secondary school education with school leaving examination .

Measures

The study uses the original Slovak scale to measure meaningfulness of life developed by Halama (2007). It is based on the theoretical concept of the three-component model of Reker and Wong (1988). It consists of three dimensions:

- Cognitive Dimension - Items related to life philosophy, life direction, understanding of life or life mission (e.g. I consider my life valuable and useful)

- Motivational Dimension - Items related to goals, plans, as well as strength and perseverance in them (e.g. there are things in my life in which I am fully involved)

- Affective Dimension - Items related to life satisfaction, fulfillment, optimism (e.g. I am happy with my life, even if it is sometimes difficult).

Each dimension consisted of 6 items in the questionnaire, so the questionnaire contained a total of 18 items. It is a valid and reliable methodological tool with Cronbach's alpha of 0.87 . Validity was assessed by establishing correlations with several scales used to determine the meaning of life (PIL, PMI, TND). Factor analysis confirmed the existence of the mentioned dimensions (Halama, 2007). The internal consistency was measured by Cronbach's alpha: cognitive component $\alpha=0.702$; motivation component $\alpha=0.685$ and affective component $\alpha=0.657$.

The Maslach Burnout Inventory MBI (1982) is the most used instrument to assess the intensity of burnout. This questionnaire included 22 items on the Likert scale in the form of statements that refer to emotions, attitudes and feelings that a person has towards work and clients/patients/pupils. These items were scored from zero to six, zero refers to a nil occurrence and six refers to one that occurs every day. These 22 items were grouped into three subscales that assessed three aspects that define the burnout syndrome according to Maslach and Jackson (1982). The MBI questionnaire contained 9 questions focusing on emotional exhaustion, 5 questions on depersonalization and 8 questions focusing on personal performance (Maslach \& Jackson, 1982). The internal consistency was measured by Cronbach's alpha with the following values: emotional exhaustion $\alpha=0.808$; depersonalization $\alpha=$ 0.672 and personal accomplishment $\alpha=0.612$.

\section{Results}

The level of burnout syndrome and meaningfulness in relation to the profession 
RQ1: Table 1 shows the average values of the level of burnout syndrome in individual domains with respect to the profession and the result of the ANOVA test aimed at identifying differences in the level of burnout syndrome. Based on the test results, it can be stated that significant differences exist in emotional exhaustion and depersonalization. In particular, based on the results of the Tukey test, there is a significant difference between teachers and nurses in terms of emotional exhaustion and depersonalization, with nurses suffering from emotional exhaustion and depersonalization to a greater extent than teachers. The level of burnout for social workers does not differ significantly from that of teachers or nurses.

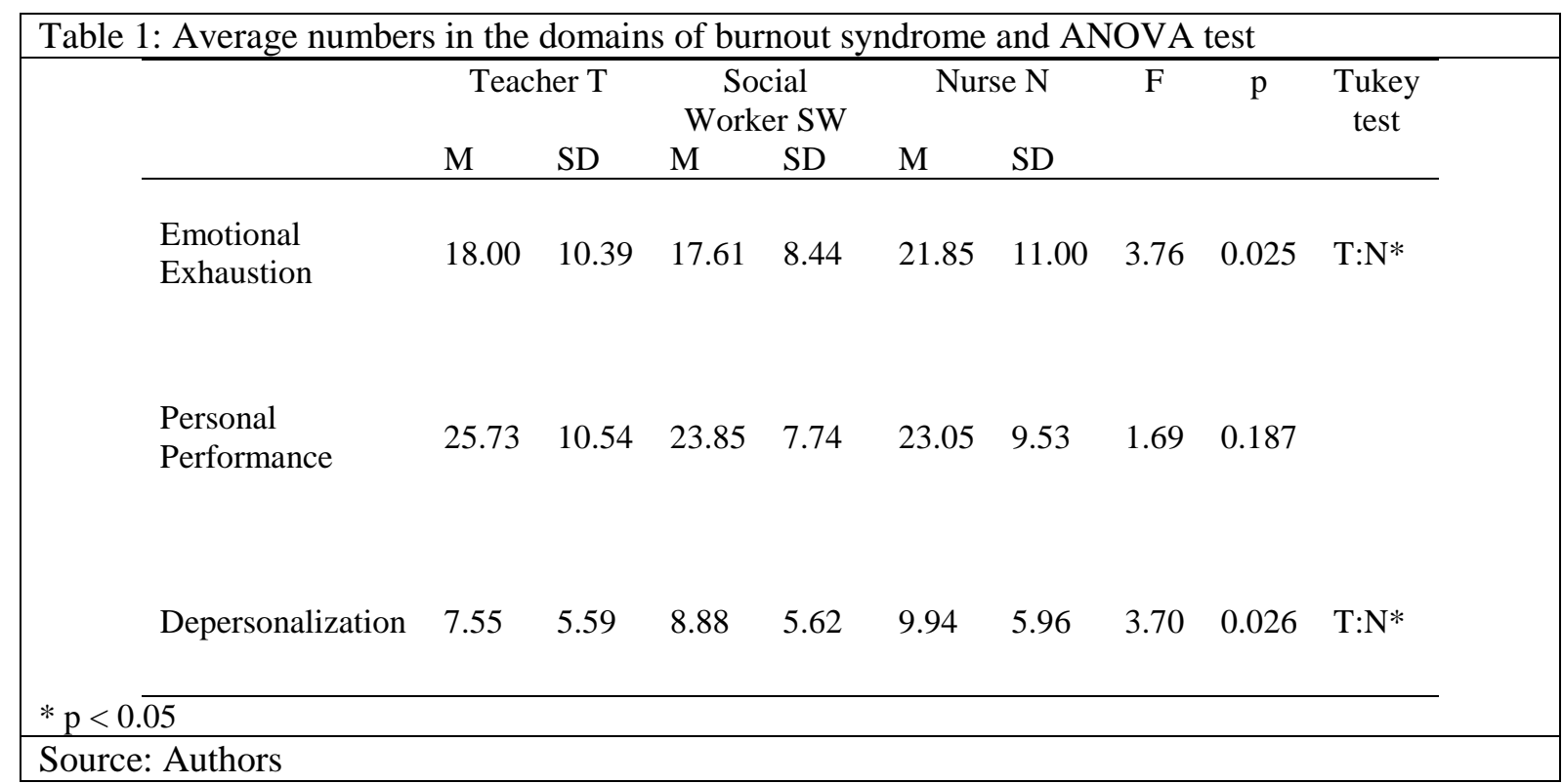

RQ2: Is there a difference in the level of meaning in life between teachers, nurses and social workers? Table 2 shows the average values of the level of vitality in individual domains with respect to the profession and the result of the ANOVA test aimed at identifying differences in the level of vitality are given. The test results found the existence of significant differences in all domains of meaning in life. As the Tukey test highlights, teachers differ in their meaning in life from both nurses and social workers, and they feel a higher level of meaning in life. Social workers and nurses do not differ significantly in the level of meaningfulness in life.

\begin{tabular}{|c|c|c|c|c|c|c|c|c|c|}
\hline & \multicolumn{2}{|c|}{ Teacher T } & \multicolumn{2}{|c|}{$\begin{array}{c}\text { Social Worker } \\
\text { SW }\end{array}$} & \multicolumn{2}{|c|}{ Nurse $\mathrm{N}$} & \multirow[t]{2}{*}{$\bar{F}$} & \multirow[t]{2}{*}{$\mathrm{p}$} & \multirow[t]{2}{*}{$\begin{array}{c}\text { Turkey } \\
\text { test }\end{array}$} \\
\hline & $\mathrm{M}$ & SD & $\mathrm{M}$ & SD & M & SD & & & \\
\hline $\begin{array}{l}\text { Cognitive } \\
\text { Component }\end{array}$ & 24.97 & 4.42 & 21.76 & 5.58 & 21.17 & 4.93 & 14.281 & 0.000 & $\begin{array}{l}\mathrm{T}: \mathrm{SW}^{* *} \\
\mathrm{~T}: \mathrm{N}^{* * *}\end{array}$ \\
\hline $\begin{array}{l}\text { Affective } \\
\text { Component }\end{array}$ & 24.43 & 4.67 & 21.78 & 4.63 & 21.43 & 4.63 & 9.973 & 0.000 & $\begin{array}{l}\mathrm{T}: \mathrm{SW}^{* *} \\
\mathrm{~T}: \mathrm{N}^{* * *}\end{array}$ \\
\hline $\begin{array}{l}\text { Motivation } \\
\text { Component }\end{array}$ & 23.32 & 3.90 & 20.93 & 4.62 & 20.24 & 4.20 & 12.346 & 0.000 & $\begin{array}{l}\mathrm{T}: \mathrm{SW}^{* *} \\
\mathrm{~T}: \mathrm{N}^{* * *}\end{array}$ \\
\hline
\end{tabular}

\section{Correlation analysis between burnout syndrome and meaning in life}

$\mathrm{H}$ : There is a statistically significant relationship between the domains of burnout syndrome and the domains of meaning in life. 
Table 3 reports the result of correlation analysis between burnout syndrome and vitality. It can be stated that the individual domains of the burnout syndrome correlate well with the domains of meaning in life, namely:

- Emotional exhaustion is negatively (weak to medium) related to individual domains of meaning in life.

- Personal performance is positively related to individual domains of meaning in life and

- Depersonalization is negatively related to the domains of meaning in life.

\begin{tabular}{|c|c|c|c|}
\hline & $\begin{array}{l}\text { Cognitive } \\
\text { component }\end{array}$ & $\begin{array}{l}\text { Affective } \\
\text { component }\end{array}$ & $\begin{array}{l}\text { Motivation } \\
\text { component }\end{array}$ \\
\hline $\begin{array}{l}\text { Emotional } \\
\text { Exhaustion }\end{array}$ & $-.278^{* *}$ & $-.355^{* *}$ & $-.320^{* *}$ \\
\hline $\begin{array}{l}\text { Personal } \\
\text { Performance }\end{array}$ & $.237^{* *}$ & $.312^{* *}$ & $.254^{* *}$ \\
\hline Depersonalization & $-.385^{* *}$ & $-.456^{* *}$ & $-.430^{* *}$ \\
\hline
\end{tabular}

RQ3: Are the components of the meaning of life and selected demographic characteristics (age, profession) a determinant of the burnout syndrome?

To assess the relative contribution of the dimensions of meaning in life to burnout dimensions, a stepwise regression was conducted (Table 4). The cognitive, affective and motivation component, professions, age were the predictors while the dependent variables were emotional exhaustion, depersonalization, and personal accomplishment.

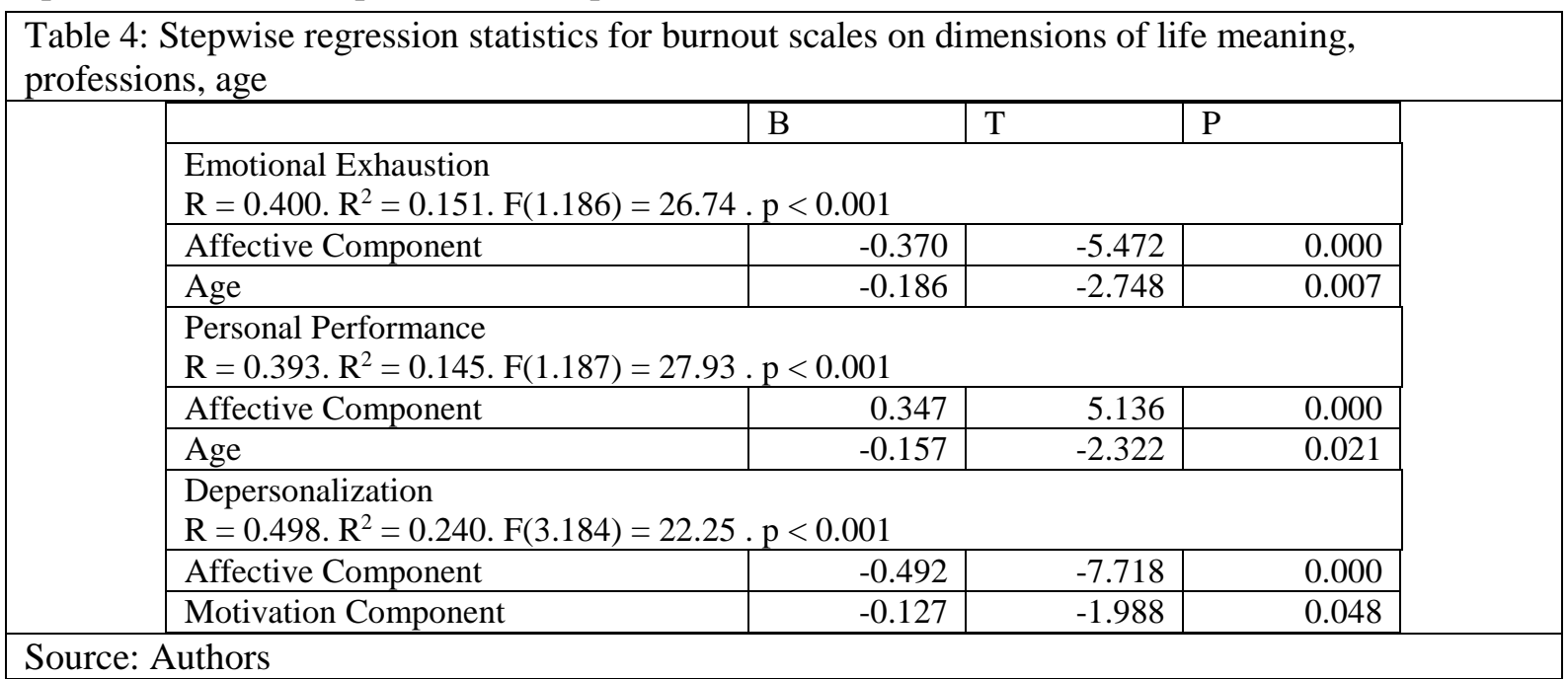

The results of stepwise regression for burnout dimensions were found to be statistically significant. The first regression model was created for emotional exhaustion (dependent variable), with significant independent variables explaining $15 \%$ variance. The predictors were affective component and age. Emotional exhaustion is higher among the respondents with a lower score in the affective component of meaning in life and in the younger workers.

The second regression model was created for personal performance as the dependent variable, with significant independent variables explaining approximately $15 \%$ of the variance. Predictors were, as in the previous model, an affective component and age. Personal performance is higher among the respondents with a high score in the affective component of meaningfulness in life and in the older workers.

The third regression model was created for depersonalization (dependent variable), with significant independent variables explaining approximately $26 \%$ of the variance. The predictors were the affective component, religion and the motivational component. Low degree of depersonalization is reported 
among the respondents with a higher score in the affective and motivational component of the meaning of life.

\section{Discussion}

The aim of this study was to identify the relationship between the meaning of life and the burnout syndrome in selected helping professions (teaching, nursing, social work). Another goal was to identify differences in the level of burnout syndrome and meaning in life between selected helping professions.

First, significant differences in the level of burnout syndrome and meaning in life between selected helping professions have been found. It has been reported that nurses were more emotionally exhausted and depersonalized than teachers. Social workers are not different in terms of emotional exhaustion and depersonalization from nurses or teachers. The level of personal performance is achieved by all the monitored professions to a similar extent. In terms of meaningfulness in life, the highest level is achieved by teachers, and this level differs significantly from nurses, who scored a lower level. As in the previous case, social workers do not differ from nurses or teachers in the meaning of life in terms of all the three components. To summarize, it can be stated that the nurses suffer from highest degree of burnout syndrome and have lowest level of meaning in life among the three professions under study. This is in accordance with the theoretical basis of the complexity of this profession. Nurses are in regular contact with fear, illness and death, as well as with the patient's relatives, which are highly stressful situations that determine mental health.

The relationship between burnout syndrome and the meaning of life has also been examined. It is found that these constructs correlate together at a weak to moderate level. The more emotionally exhausted a worker is, the lower is the meaning of life in terms of cognitive, affective and motivational components. Similarly, the more he suffers from depersonalization, the lower is the meaning of life with respect to all the three components. Finally, the higher the level of personal performance of an employee, the higher is the meaningfulness of life in all the individual components.

To evaluate the relative impact of vitality on the burnout syndrome, stepwise regression analysis was performed. It has been found that the affective component of meaning of life and age are the predictors of emotional exhaustion and personal performance. The predictors of depersonalization are the affective and motivating components of meaning of life.

The affective component of the meaning of life is related to the experience of fulfillment, happiness and contentment that results from meaningful life. On the contrary, an underdeveloped affective component is associated with dissatisfaction, sadness, anxiety, pessimism (Reker \&Wong, 1988). If an individual is emotionally exhausted, it will also be reflected in his affective experience of the meaning of life. An emotionally exhausted worker experiences the exhaustion of his emotional and physical resources, loses his zest for life, does not have enough strength to carry out activities, and this is reflected in the affective experience through the feelings of dissatisfaction.

Similarly, if he suffers from reduced personal performance, he feels incompetent, he has low selfconfidence, this is manifested especially in the affective component of the meaning of life. Age is also a predictor of emotional exhaustion and reduced personal performance, and the younger workers are reported to suffer from burnout syndrome to a greater extent. As confirmed by Maslach et al. (2001), from demographic characteristics, age appears to be a variable that is consistently linked to burnout, with younger workers being more prone to burnout. In the present study, age is a predictor of emotional exhaustion and reduced personal performance, but not of depersonalization.

The predictors of depersonalization are affective and motivating components of meaning of life. Depersonalization is manifested by an impersonal, insensitive, cynical, indifferent attitude towards clients, patients or students. In connection with the meaning of life, it is manifested in its affective component by dissatisfaction, pessimism and in its motivational component by manifestation of apathy, boredom, hopelessness, lack of motivation regarding the possible achievement of goals.

It seems that a firm belief in the meaning of life is useful and beneficial in alleviating the negative work aspects that can lead to burnout in the helping professions. These results are consistent with the findings of several previous studies by Loonstra et al. (2009); Gama et al. (2014); Meriläinen (2014); Itzick et al. (2016); Allan et al. (2017); Kohútová(2017); Barnett et al. (2018); Singer et al. (2019); Hooker et al. (2020) and also with clinical observations of Pines (2002). The present study supports 
the results of these cited studies and confirms the established hypothesis. It is believed that the meaning of life can be one of the protective psychological factors against burnout. Other factors include type B personality, hardness, optimism, social support, good interpersonal relationships, favorable working conditions, good work organization, intrinsic locus of control (Maslach \& Leiter, 1997; Křivohlavý, 2006; Kupka, 2011).

Having a meaningful vision of life is especially important for helping professionals, whose work requires high demands on resilience and coping with stressful situations. It is important that social workers, teachers and nurses find meaning in their work, which will give them the strength to continue even in difficult conditions. Meaningful life can support personal growth and self-realization. For the counselling and therapy of a burned-out individual, it is appropriate to use an existential approach and logotherapy, which are focused on finding the meaning of life. Pines (2002) emphasized the connection between existential and psychodynamic approach, in which it is important to focus on:

- Identifying the conscious and unconscious reasons for the individual's career choice and how the chosen career was expected to provide a sense of existential significance.

- Identifying the reasons for the individual's failure to derive a sense of existential significance from the work and how this sense of failure is related to burnout.

- Identifying changes that will enable the individual to derive a sense of existential significance from work.

\section{Conclusions}

Meaningfulness of life can act as a regulator of the ability to manage stress by positively supporting the mobilization of various coping strategies and reducing the degree of perception of situations as stressful (e.g. perception of a problem situation as a challenge rather than a threat). An individual's beliefs, values, and goals that give meaning to an individual can provide a basis for selecting and implementing appropriate stress management strategies. Meaningful life can be a source of strength that will allow workers to continue their work even in difficult work situations.

\section{Limitations}

The presented study has several limits and limitations. First, all analyzes were correlated and crosssectional, meaning that it is not possible to talk about causal relationships. On the other hand, it is possible to assume that a certain connection between the meaning of life and the burnout syndrome exists, as the results of the study suggest, as well as the results of the previous studies cited above. Second, the research sample is representative only for the districts of Dolný Kubín and Námestovo (Slovakia), therefore the intercultural generalizability of these findings is problematic, as working conditions and professional values differ in different countries. Third, the results may have been influenced by the degree of introspection of the respondents, which is a typical limitation in the use of self-assessment scales.

\section{References}

Allan, B. A., Owens, R. L., \& Douglass, R. P. (2017). Character Strengths in Counselors. Journal of Career Assessment, 116.

Baranovská, A. (2013). Potreba kognitívnej štruktúry vo vt’ahu k emocionálnemu vyhoreniu u učitel’ov. [The need for cognitive structure in relation to emotional burnout in teachers] In Proceedings of the Conference on Social Processes \& Personality, 20-23.

Barnett, M. D., Moore, J. M. \& Garza, C. J. (2018). Meaning in life and self-esteem help hospice nurses withstand prolonged exposure to death. Journal of Nursing Management, 27(4), 775-780.

Bočáková, O. \& Rolníková, B. (2005). Efekt vyhorenia a stres v učitel’skej a zdravotníckej profesii. [The effect of burnout and stress in the teaching and medical profession] In M. Šramka, \& Bérešová, A., Komplexná starostlivost'o človeka v hraničných situáciách (s. 28-35). Prešov: Fakulta zdravotníctva a sociálnej práce.

Frankl, V. E. (1983). Theorie und Therapie der Neurosen. Munich: Reinhardt.

Gama, G., Barbosa, F. \& Vieira, M. (2014). Personal determinants of nurses' burnout in end of life care. European Journal of Oncology Nursing, 18(5), 527-533.

Halama, P. (2007). Zmysel života z pohl'adu psychológie. [The meaning of life from the point of view of psychology] Bratislava: SAP.

Halama, P. et al. (2014). Vzt’ah medzi prežívaným stresom a zmysluplnost'ou života mladých a starších dospelých. Osobonostné črty ako mediátory. [The relationship between experienced stress and the meaning of life of young and older adults. Personality features as mediators] Československá psychologie, LVIII(5), 442-454. 
Hooker, S. A., Post, R., \& Sherman, M. (2020). Awareness of Meaning in Life is Protective Against Burnout Among Family Physicians: A CERA Study. Family Medicine, 52(1), 11-16.

Itzick, M., Kagan, M. \& Ben-Ezra, M. (2016). Social worker characteristics associated with perceived meaning in life. Journal of Social Work, 18(3), 326-347.

Kohútová, K. (2017). Teoreticko-metodologické východiská problematiky syndrómu vyhorenia v kontexte kvality života. [Theoretical and methodological basis of the issue of burnout syndrome in the context of quality of life] Ružomberok: Verbum.

Krok, D. (2016). Can meaning buffer work pressure? An exploratory study on styles of meaning in life and burnout in firefighters. Archives of Psychiatry and Psychotherapy, 1, 31-42.

Křivohlavý, J. (2006). Psychologie smysluplnosti existence - Otázky na vrcholu života. [Psychology of the meaningfulness of existence - Questions at the peak of life] Praha: Grada.

Kupka, M. (2011). Psychologické aspekty paliativní péče. [Psychological aspects of palliative care] Olomouc: Univerzita Palackého.

Längle, A. M. (2003). Burnout - Existential Meaning and Possibilities of Prevention. European Psychotherapy, 4(1), 107122.

Lloyd, C., King, R. \& Chenoweth, L. (2002). Social work, stress and burnout: A review. Journal of Mental Health, 11(3), 255-265.

Loonstra, B., Brouwers, A. \& Tomic, W. (2009). Feelings of existential fulfilment and burnout among secondary school teachers. Teaching and Teacher Education, 25(5), 752-757.

Maslach, C. (1982). Burnout: The cost of caring. Engelwood Cliffs: NJ: Prentice Hall.

Maslach, C. \& Jackson, S. E. (1982). Burnout in health professions: a social psychological analysis. In G. S. Sanders, \& J. M. Suls, Social Psychology of Health and Illness. Hillsdale: Laurence Eribaum Associates.

Maslach, C. \& Leiter, M. P. (1997). The truth about burnout. San Francisco: Jossey-Bass.

Maslach, C., Schaufeli, W. B. \& Leiter, M. P. (2001). Job Burnout. Annual Review of Psychology, 52(1), 397-426.

Meriläinen, M. (2014). Factors affecting study-related burnout among Finnish university students: teaching-learning environment, achievement motivation and the meaning of life. Quality in Higher Education, 20(3), 309-329.

Nantsupawat, A., Nantsupawat, R., Kunaviktikul, W., Turale, S., \& Poghosyan, L. (2016). Nurse Burnout, Nurse-Reported Quality of Care, and Patient Outcomes in Thai Hospitals. Journal of Nursing Scholarship, 48(1), 83-90.

Pilárik, L'. \& Tobákošová, Z. (2013). Emocionálna inteligencia a syndróm vyhorenia u sestier. [Emotional intelligence and burnout syndrome in nurses] Ošetrovatel'stvo (teória, výskum, vzdelávanie), 3(1), 5-10.

Pines, A. M. (2002). A psychoanalytic-existential approach to burnout: Demonstrated in the cases of a nurse, a teacher, and a manager. Psychotherapy: Theory, Research, Practice, Training, 39(1), 103-113.

Pines, A. M. \& Keinan, G. (2005). Stress and burnout: The significant difference. Personality and Individual Differences, 39(3), 625-635.

Pines, A. \& Aronson, E. (1983). Combatting burnout. Children and Youth Services Review, 5(3), 263-275.

Reker, G. T. \& Wong, P. P. (1988). Aging as an individual process: Toward a theory of personal meaning. In J. E. Birren, \& V. L. Bengtson, Emergent theories of aging (pp. 214-246). Springer Publishing Company.

Reker, G. T. \& Woo, L. C. (2011). Personal Meaning Orientations and Psychosocial Adaptation in Older Adults. SAGE open, 1-10. https://doi.org/10.1177/2158244011405217Singer, J., Cummings, C., Moody, S. A., \& Benuto, L. T. (2019). Reducing burnout, vicarious trauma, and secondary traumatic stress through investigating purpose in life in social workers. Journal of Social Work, 20(5), 1-19.

Soto-Rodríguez, A. \& Peréz-Fernandez, M. R. (2015). Burnout Syndrome and Stress of Nursing Staff in a Ourense Hospital. Revista de enfermeria (Barcelona, Spain), 38(2), 21-27.

Slezáčková, A. \& Ř́íhová, P. E. (2014). Životní smysluplnost a interpersonální hodnoty jako protektivní faktory syndromu vyhoření u zdravotních sester. [Life meaningfulness and interpersonal values as protective factors of burnout syndrome in nurses] Annales psychologici, 15(1), 45-60.

Yalom, I. D. (1980). Existential PsychotherapyBasic Books. New York: Library of Congress Cataloging in Publication Data.

Zacharová, E., Hermanová, M. \& Šrámková, J. (2007). Zdravotnicka psychologie - teorie a praktická cvičení. [Medical psychology - theory and practical exercises] Praha: Grada Publishing. 